\title{
HUBUNGAN PEMBERIAN SUSU MENGGUNAKAN BOTOL DENGAN RAMPAN KARIES PADA MURID TK HJ. CUT NYAK AWAN GAMPONG LAMBARO \\ KEC. INGIN JAYA KAB. ACEH BESAR
}

\author{
Elfi Zahara ${ }^{1}$, Andriani ${ }^{1}$ \\ ${ }^{1}$ Jurusan Keperawatan Gigi Poltekkes Kemenkes Aceh, Jl. Soekarno Hatta Desa Lagang Kabupaten Aceh Besar \\ *Corresponding author : elfizahara98@gmail.com
}

\begin{abstract}
Abstrak
Pada umumnya susu botol diberikan pada balita sepanjang hari sejak anak bermain sampai tidur sehingga rampan karies bisa tinggi terjadi pada anak (Afnilina,2006). Penelitian ini bersifat analitik dengan menggunakan desain cross sectional untuk mengetahui hubungan pemberian susu dengan menggunakan botol terhadap rampan karies pada murid TK Hj. Cut Nyak Awan Aceh Besar Tahun 2018. Subjek penelitian ibu dan anak yang berjumlah 148 orang. Alat ukur penelitian adalah angket untuk mengukur cara pemberian susu dengan menggunakan botol serta pemeriksaan rampant karies dengan menggunakan indeks def-t. Analisi data menggunakan uji statistik chi-square. Hasil penelitian :Ada hubungan antara cara pemberian susu menggunakan botol dengan rampan karies $(\mathrm{p}=0,000)$. Cara pemberian susu kurang baik, ada rampan karies pemberian susu baik ts $95,4 \%$, cara pemberian susu baik tidak ada rampan karies $63,6 \%$. ada hubungan signifikan antara frekwensi pemberian susu menggunakan botol dengan rampan Karies $(\mathrm{p}=0,00)$ frekwensi pemberian sampai tertidur ada rampan karies $89,0 \%$ frekwensi pemberian menjelang tidur tidak ada rampan karies( $64,3 \%)$.
\end{abstract}

Kata Kunci : cara pemberian susu menggunakan botol; rampan karies

\section{RELATIONSHIP GIVING MILK BOTTLE WITH USING THE STUDENT KINDERGARTEN RAMPAN CARIES HJ . CUT NYAK AWAN GAMPONG LAMBARO KEC . INGIN JAYA KAB . ACEH BESAR}

\begin{abstract}
Abstrack
In general, a bottle of milk given to children throughout the day from children playing until bedtime Rampan high caries in children. (Afnilina, 2006). This research is analytic by using cross-sectional design to determine the relationship of feeding with a bottle against Rampan caries in kindergarten Hj .Cut Nyak Cloud Aceh Besar 2018. The research subjects mother and child, amounting to 148 people. Measuring instrument was a questionnaire study to measure how feeding with a bottle and rampant caries examination using def index $-t$. Data analysis using the chi-square test statistic . Results: There is a correlation between the method of feeding a bottle with a caries rampan $(\mathrm{p}=0,000)$. There is a significant relationship between the frequency of giving milk by bottle with tray of caries $(\mathrm{p}=$ 0.00 ) the frequency of administration to sleep was caries caries $89.0 \%$ of the frequency of bedtime giving no caries rampan $(64.3 \%)$.
\end{abstract}

Keyword: how to use bottle feeding, rampan caries

Jurnal Averrous Vol.4 No.1 2018 


\section{Pendahuluan}

Kesehatan gigi dan mulut sebagai bagian dari kesehatan badan, ikut berperan dalam menentukan status kesehatan seseorang. Untuk menilai status kesehatan gigi dapat di lihat dari ada dan tidak nya penyakit gigi, di antaranya karies gigi. Karies gigi merupakan penyakit gigi yang paling banyak di temukan, meliputi semua usia dan lapisan masyarakat yang jika tidak di ketahui sejak dini dan di biarkan berlanjut dapat menjadi lebih parah. Selain itu timbul pula komplikasi yang serius berupa penyakit ginjal, jantung, saraf dan sebagainya ${ }^{15}$

Pada usia dini atau anak balita sering di jumpai kelainan karies gigi (rampan karies), kehilangan gigi terlalu dini pada anak balita dapat mempengaruhi pertumbuhan dan perkembangan gigi tetap dan rahang anak tersebut, keadaan ini dapat mengganggu fungsi estetika wajah.

Ada beberapa penyebab yang mempengaruhi kerusakan gigi pada anak,diantaranya penggunaan susu botol ,banyak orang tua yang mengeluh banyak gigi anak kecoklatan,mahkota gigi yang rusak,bahkan terkadang sudah tinggal sedikit saja mahkota yang tersisa namun banyak para ibu yang tidak menyadari apa penyebab yang sesungguhnya terjadi pada gigi anaknya tersebut yaitu mengalami karies botol (Rampan Karies).

Penyakit yang ditandai dengan munculnya karies disekitar gigi seri atas dan geraham besar itu kini banyak di temukan pada anak usia 3-6 tahun di negara berkembang dengan prevalensi 90\%. Rampan karies dapat terjadi karena zat asam erosiv, konsentrasi asam yang tinggi dapat menyebabkan demineralisasi dan menyebabkan karies. Banyak orang tua yang berfikir gigi susu kurang penting untuk dirawat karena akan di gantikan oleh gigi tetap. Namun gigi pertama ini berfungsi untuk membentuk rahang dan menyediakan tempat untuk gigi tetap. Jika tidak dirawat gigi susu akan berlubang dan dapat menyebabkan infeksi gusi dan mempengaruhi letak gigi permanen ${ }^{6}$

Faktor kejadian karies gigi antara lain faktor dari makanan, kebersihan mulut, kebiasaankebiasaan yang tidak sesuai dengan kesehatan seperti mengemut makanan dan pemberian makanan melaui botol.selain dari faktor kebiasaan dan faktor makanan, kondisi yang memperparah terjadinya karies pada anak ini adalah karena ketidak pahaman orang tua terhadap penyebab utama terjadinya karies tersebut, dimana karies tersebut dipicu oleh pemberian larutan yang manis seperti air susu, soft drink menggunakan botol, serta air susu 
ibu yang cara pemberian, frekuensi serta intensitasnya kurang tepat. Lamanya larutan tersebut berada di rongga mulut, seperti ketika anak tertidur sambil mengemut(mengedot)softdrink, air susu dalam botol lebih memperparah terjadinya rampan karies pada gigi anak.

Organisasi kesehatan dunia(WHO) pada tahun 2003 menyatakan angka kejadian karies gigi pada anak masih sebesar $60-90 \%$. Penelitian taverud menunjukkan bahwa prevalensi karies gigi pada anak berusia satu tahun sebesar 5\%, anak usia dua tahun sebesar $10 \%$, anak usia tiga tahun sebesar $40 \%$, anak usia empat tahun sebesar 55\%, dan anak usia lima tahun sebesar $75 \%$. Dengan demikian golongan umur balita atau usia dini merupakan golongan rawan terjadinya karies gigi ${ }^{16}$

Penelitian yang dilakukan oleh Rahmi ${ }^{15}$ menunjukkan bahwa prevalensi karies gigi pada anak sangat bervariasi jika didasarkan atas golongan umur dimana anak usia 1 tahun sebesar 5\%, anak usia 2 tahun $10 \%$, anak usia 3 tahun $40 \%$, anak usia 4 tahun $55 \%$, dan anak usia 5 tahun $75 \%$. Dengan demikian golongan umur balita merupakan golongan rawan terjadinya karies gigi. Pada balita dan anak pra sekolah sering di jumpain kelainan karies gigi yang menyeluruh(rampan karies) yaitu karies yang terjadi tiba-tiba, mengenai banyak gigi dalam waktu singkat, dan cepat melibatkan pulpa. Keries rampan mempunyai karakteristik terkenanya permukaan proximal gigi insicivus bawah yang berkembang hingga mengenai daerah servikal.

TK Hj. Cut Nyak Awan merupakan salah satu TK yang terletak di gampong lambaro kecamatan. Ingin Jaya, kabupaten Aceh Besar yang memiliki murid berjumlah 148 orang. Berdasarkan wawancara awal peneliti dengan 10 orang tua (ibu) murid mereka mengatakan bahwa anaknya selalu di berikan susu dengan menggunakan botol. Hasil pemeriksaan awal terhadap 10 orang murid TK. HJ. Cut Nyak Awan banyak di jumpain kasus rampan karies dan indek def-T terdapat pada kategori sedang 4,00. Hal ini tidak sesuai dengan target yang telah di tetapkan pemerintah yaitu DMF-T $\leq 2$.

Berdasarkan latar belakang diatas, maka tujuan penelitian ini adalah untuk mengetahui untuk mengetahui hubungan pemberian susu menggunakan botol dengan rampan karies pada murid TK Hj. Cut Nyak Awan Lambaro Aceh Besar, sehingga peneliti dapat mengetahui hubungan cara pemberian susu menggunakan botol dengan rampan karies ,mengetahui hubungan frekuensi pemberian susu menggunakan botol dengan rampan karies pada murid $\mathrm{TK} \mathrm{Hj}$. Cut 
Nyak Awan Lambaro Aceh Besar Tahun 2018.. Penelitian diharapkan dapat bermanfaat bagi Instansi terkait dalam upaya meningkatkan status kesehatan gigi dan mulut murid $\mathrm{TK} . \mathrm{Hj}$. Cut Nyak Awan Lambaro Aceh Besar.

\section{Metode}

Jenis penelitian ini adalah analitik yaitu untuk mengetahui hubungan cara pemberian susu menggunakan botol dan frekuensi menggunakan susu botol dengan rampan karies dengan desain cross sectional . Populasi pada penelitian ini adalah seluruh murid dan ibunya di Tk. Hj Cut Nyak Awan A. Besar sebanyak, 87 ibu dan 87 murid. Sampel dalam penelitian ini adalah ibu dan anak yang dipilih secara purposive, yaitu dengan kriteria inklusi : anak usia 3-6 tahun dan menggunakan susu botol serta ibu yang mempunyai anak usia 3-6 tahun yang memberikan susu dengan menggunakan botol.Pengumpulan data diperoleh langsung berdasarkan hasil wawancara pada ibu dengan menggunakan angket dan pemeriksaan kepada anak.Analisa data terdiri dari a). Analisa Univariat untuk mengetahui distribusi frekuensi dari setiap variable independent, b) Analisa Bivariat untuk mengetahui hubungan antara variable independent yaitu cara pemberian susu menggunakan botol dan frekuensi pemberian susu menggunakan botol dengan variable dependent yaitu rampan karies. Dalam analisa ini dilakukan pengujian analitik dengan uji chi-square $(\alpha=0.05)$ menggunakan program Statistik Program for Social Scince (SPSS).

\section{Hasil Penelitian}

Penelitian ini dilaksanakan pada tanggal pada 19 s/d 24 februari 2018 pada Ibu dan murid di Tk Hj. Cut Nyak Awan Lambaro, A. Besar dengan jumlah sampel 87 orang ibu dan 87 murid, maka didapatkan hasil penelitian sebagai berikut:

Tabel 1. Distribusi Responden Berdasarkan jenis kelamin di TK Hj. Cut Nyak Awan Gampong Lambaro Kec. Ingin Jaya Kab. Aceh Besar Tahun 2018.

\begin{tabular}{llcc}
\hline No & Jenis kelamin & Frekuensi & Persentase(\%) \\
\hline 1 & Laki-laki & 36 & 41 \\
2 & Perempuan & 51 & 59 \\
& Total & 87 & 100 \\
\hline
\end{tabular}


Tabel. 2 Distribusi Responden Berdasarkan jenis pekerjaan ibu pada murid TK. Hj. Cut Nyak Awan Gampong Lambaro Kec. Ingin Jaya Kab. Aceh Besar Tahun 2018.

\begin{tabular}{llcc}
\hline No & Pekerjaan ibu & Frekuensi & Persentase(\%) \\
\hline 1 & IRT & 72 & 82 \\
2 & PNS & 12 & 15 \\
3 & SWASTA & 3 & 3 \\
& Total & 87 & 100 \\
\hline
\end{tabular}

Tabel 3. Distribusi responden cara pemberian susu menggunakan botol pada murit TK TK. Hj. Cut Nyak Awan Gampong Lambaro Kec. Ingin Jaya Kab. Aceh Besar Tahun 2018.

\begin{tabular}{llcc}
\hline No & Kategorik & Jumlah & Persentase(\%) \\
\hline 1 & Kurang baik & 65 & 74,7 \\
2 & Baik & 22 & 25,3 \\
& Total & 87 & 100 \\
\hline
\end{tabular}

Tabel 4. Distribusi frekuensi responden pemberian susu menggunakan botol

\begin{tabular}{llcc}
\hline No & Kategorik & Jumlah & Persentase(\%) \\
\hline 1 & Sampai tidur & 73 & 83.9 \\
2 & Menjelang tidur & 14 & 16,1 \\
& Total & 87 & 100 \\
\hline
\end{tabular}


Tabel 5. Distribusi responden berdasarkan rampan karies murid TK. Hj. Cut Nyak Awan Gampong Lambaro Kec. Ingin Jaya Kab. Aceh Besar Tahun 2018.

\begin{tabular}{llcc}
\hline No & Rampan karies & Jumlah & Persentase(\%) \\
\hline 1 & Ada & 70 & 80,5 \\
2 & Tidak ada & 17 & 19,5 \\
& Total & 87 & 100 \\
\hline
\end{tabular}

Tabel 6

Hubungan cara pemberian susu menggunakan botol dengan rampan Karies pada murid di TK. Hj. Cut Nyak Awan Gampong Lambaro Kec. Ingin Jaya Kab. Aceh Besar Tahun 2018.

\begin{tabular}{llllll}
\hline No & $\begin{array}{c}\text { Cara Pemberian } \\
\text { susu }\end{array}$ & Ada $\%$ & $\begin{array}{c}\text { Tidak } \\
\text { ada } \%\end{array}$ & Total & $\begin{array}{l}\text { Hasil Analisis } \\
\text { Statistisk }\end{array}$ \\
\hline 1 & Kurang Baik & $62(95,4 \%)$ & $3(4,6 \%)$ & $65(100 \%)$ & Df $=1$ \\
2 & Baik & $8(36,4)$ & $14(63,6)$ & $22(100 \%)$ & $\mathrm{P}=0,000$ \\
& Total & $70(80,5)$ & $17(19,5)$ & $87(100 \%)$ & 100 \\
\hline
\end{tabular}

Tabel 7 Hubungan Frekwensi pemberian susu menmggunakan botol dengan rampan karies pada murit murid di TK. Hj. Cut Nyak Awan Gampong Lambaro Kec. Ingin Jaya Kab. Aceh Besar Tahun 2018

\begin{tabular}{lccccc}
\hline No & Frekwensi & \multicolumn{2}{c}{ Rampan Karies } & & $\begin{array}{l}\text { Hasil Analisis } \\
\text { Statistisk }\end{array}$ \\
\cline { 3 - 4 } & pemberian susu & Ada $\%$ & $\begin{array}{c}\text { Tidak } \\
\text { ada\% }\end{array}$ & \\
\hline 1 & Sampai tertidur & $65(89,0 \%)$ & $8(11,0 \%)$ & $73(100 \%)$ & Df $=1$ \\
2 & Menjelang tidur & $5(35,7)$ & $9(64,3 \%)$ & $14(100 \%)$ & $\mathrm{P}=0,000$ \\
& Total & 70 & 17 & $87(100 \%)$ & \\
\hline
\end{tabular}




\section{Pembahasan}

1. Cara pemberian susu menggunakan botol

Hasil uji statistik menunjukkan ada hubungan cara pemberian susu menggunakan botol dengan rampan karies $(\mathrm{P}=0,000)$.

Cara pemberian susu kurang baik ada rampan karies sebesar 95,4\%. Menurut pendapat peneliti ${ }^{12}$ masih minimnya pengetahuan orang tua tentang cara pemberian susu yang baik dan cara pencegahan karies sehingga pada saat memberikan susu menggunakan botol, anak-anak tidak dilakukan pembilasan, berkumur-kumur dengan air putih ataupun menggosok gigi.

Hal ini sesuai dengan pendapat Nelson, kebanyakan ibu tidak menyadari pentingnya menjaga kesehatan gigi dan mulut anak, dengan susu botol sampai tertidur menyebabkan anak yang minum susu atau minuman manis menjelang tidur sampai tertidur dengan periode pemberian yang terlalu lama yakni, lebih dari dua tahun dan dengan posisi dot botol dalam rongga mulut maka cairan manis akan membasahi permukaan gigi sulung terutama insisif, molar atas dan molar bawah, pada keadaan tersebut jumlah aliran saliva menurun dan kualitas saliva mengental sehingga efek pembersihan saliva berkurang, lingkungan demikian akan meningkatkan kualitas bakteri kariogenik, hasil fermentasi antara sukrosa dan bakteri menurunkan ph saliva sehingga lingkungan rongga mulut menjadi asam permukaan gigi yang terkena akan mengalami demineralisasi dan akhirnya karies.

Cara memberikan susu botol perlu diperhatikan sejak awal ,susu botol diberikan pada saat anak terjaga ,dalam keadaan terpangku,balita yang diberikan susu botol sambil dipangku oleh ibu atau ayahnya, jarang sekali menjadi begitu lekat pada botolnya karena mereka sudah mendapatkan kasih sayang dan perhatian dari orangtuanya pada saat memberikan minum,balita yang sudah cukup perhatian dari orangtuanya akan mudah dialihkan untuk minum dengan menggunakan cangkir dan dapat lebih mudah untuk membiasakan anak untuk minum air putih setelah minum susu untuk menghilangkan sisasisa susu yang masih melekat pada gigi ${ }^{1}$ 
Pemberian susu menggunakan botol biasanya di berikan kepada bayi dengan terus menerus tanpa dilakukan bilasan air putih atau tanpa diikuti pembersihan sisa dari susu yang tertinggal dalam rongga mulut ${ }^{12}$

Sebenarnya hal tersebut tidak akan menjadi masalah bila sesudah mengkonsumsi makanan yang mengandung gula hendaknya gigi segera dibersihkan paling tidak dengan berkumur $^{10}$

2. Frekuensi pemebrian susu menggunakan botol dengan rampan karies

Hasil uji statistik menunjukkan ada hubungan antara frekuensi pemberian susu menggunakan botol dengan rampan karies $(p=0,000)$. Frekuensi pemberian susu sampai tertidur ada rampan karies $89,0 \%$. Penulis berasumsi bahwa pada saat tidur, gigi-gigi rahang bawah akan tertutup lidah sehingga genangan air susu akan lebih menyerang gigi atas. Hal ini sesuai dengan penelitian Nugroho, dkk bahwa ada hubungan antara waktu pemberian susu botol dengan kejadian karies gigi. hal ini di buktikan bahwa kejadian kejadian karies gigi lebih tinggi pada anak yang diberikan susu botol sampai tidur, dibandingkan dengan kejadian kejadian karies pada anak yang diberikan susu botol menjelang tidur, ibu yang memberikan susu botol sampai tidur dapat meningkatkan resiko terjadinya karies lebih tinggi dibandingkan ibu yang memberikan susu botol hanya sampai menjelang tidur.

Berdasarkan penelitiansupeni bahwa cara minum susu menjelang tidur lebih besar peluang terkena karies gigi dibandingkan dengan anak yang minum susunya tidak sampai tidur, waktu minum susu tidak sampai tidur dapat mencegah terjadinya karies gigi.

Anak yang minum susu atau cairan manis lainnya melalui botol pada waktu tidur maka cairan dari botol atau susu yang diminum anak akan tergenang didalam mulut dalam waktu yang lama.kecepatan kerusakan gigi akan jelas terlihat dengan timbulnya karies menyeluruh dalam waktu singkat.

\section{Kesimpulan dan Saran}

1. Setelah dilakukan penelitian, dapat disimpulkan sebagai berikut :

2. Ada hubungan antara cara pemberian susu menggunakan botol dengan rampan karies $(\mathrm{p}=0,000)$. Cara pemberian susu kurang baik, ada rampan kariea pemberian susu baik ts $95,4 \%$, cara pemberian susu baik tidak ada rampan karies $63,6 \%$. 
3. Ada hubungan signifikan antara frekwensi pemberian susu menggunakan botol dengan rampan Karies $(\mathrm{p}=0,00)$ frekwensi pemberian sampai tertidur ada rampan karies $89,0 \%$ frekwensi pemberian menjelang tidur tidak ada rampan karies( 64,3\%)

\section{Berdasarkan kesimpulan yang telah disebutkan di atas, maka dapat direkomendasikan :}

1. Diharapkan kepada orang tua untuk dapat meningkatkan perilaku, khususnya pengetahuan tentang kesehatan gigi dan mulut anak, agar anak selalu sehat dan terhindar dari penyakit gigi dan mulut, sehingga tidak mengganggu konsentrasi anak dalam beraktifitas sertatidak menghambat tumbuh kembang anak.

2. Diharapkan kepada orang tua untuk dapat menghilangkan kebiasaan buruk kepada anaknya dengan tidak membiarkan anak tertidur dengan susu botol, dan menyuruh anak anak untuk melakukan pembilasan,berkumur - kumur dengan air putih ataupun menggosok gigi.

\section{Ucapan Terima Kasih}

Penulis mengucapkan terima kasih yang sebesar-besarnya kepada pihak PPSDM yang telah memfasilitasi dalam penyusunan artikel ilmiah, BKKBN Kota Banda Aceh dan mahasiswa Fakultas Kesehatan Masyarakat yang telah membantu dalam pengumpulan data. Serta semua pihak yang telah membantu terlaksananya penelitian ini.

\section{Daftar Kepustakaan}

1. Afrilina,Gralianti,2006, 75 masalah gigi anak dan Solusinya,Gramedia,Jakarta

2. Astoeti, T.E., Jenie, I., Kusnoto,J., 2003, Hubungan Perilaku Terhadap Kebersihan Gigi dan Mulut Murid-Murid Sekolah Dasar Negeri DKI Jakarta Penderita Gigi Berjejal, Jurnal Kedokteran Gigi Indonesia, Universitas Indonesia, Jakarta

3. Azwar,S., 2003, Sikap Manusia Teori dan Pengukurannya, Edisi ke 2, Pustaka Pelajar, Yogyakarta Hamsafir E, 2010. Perawatan Gigi Pada Anak.

4. Budiharto, 2009, Pengantar Ilmu Perilaku Kesehatan dan Pendidikan Kesehatan Gigi, EGC, Jakarta.

5. Kidd, Edwina A. M, dkk, dasar-dasar karies penyakit dan penangulangannya, EGC. Jakarta

6. Hamsafir E, 2010. Perawatan Gigi Pada Anak.

7. Hidayat, D. dan Murdanu, 1997, Pendidikan Orang Tua Dalam Upaya Meningkatkan Mutu Pendidikan Anak, Cakrawala Pendidikan.

8. Khairuddin, 2008, Sosiologi Keluarga, Liberty, Yogyakarta

9. Kemp, J, dan Walters, C., 2004, Gigi Si Kecil : Cara Menjaga Kesehatan Gigi Dan Gusi Anak, Seri Panduan Praktis Keluarga, (Terj),Erlangga, Jakarta.

10. Machfoedz I, 2008, menjaga kesehatan gigi dan mulut anak-anak dan ibu hami, Jakarta 
11. Mahafundo,2008,Penanganan karies, http //www.google.com

12. Maulani, C. Jubilee, 2005, Kiat Merawat Gigi Anak, Panduan Orang Tua Dalam Merawat Dan Menjaga Kesehatan Gigi Bagi Anak-Anaknya. PT Elex Media Komputindo. Jakarta

13. Nelson, 2002, definisi rampan karies .http//www. Rampankaries.co.id. diakses tanggal 10 februari 2014.

14. Noatmojo, S, 2003.Pendidikan kesehatan dan ilmu prilaku, EGC. Jakarta.

15. Rahmi, 2011. Minum Susu Botol Picu Karies Gigi Anak.

16. Soleman, 2009, Prevalensi Karies Gigi Pada Balit, http//soleman. Blogspot.com

17. Suwelo, 1992, Karies Gigi Pada Anak dengan Berbagai Faktor Etiologi, Buku Kedokteran EGC, Jakarta.

18. Sudarma, M., 2008, Sosiologi Untuk Kesehatan, Salemba Medika, Jakarta

19. Suharja, E.S., 2006, Efektifitas Pendidikan Kesehatan Gigi Antara Metode Ceramah Dengan Modul Dan Tanpa Modul Terhadap Pengetahuan, Persepsi, Motivasi, Perilaku Dan Kesehatan Gigi Dan Mulut Santri Usia 12-14 Tahun, Tesis, Program Pascasarjana UGM, Yogyakarta.

20. Sriyono, N, W., 2007, Pengantar Ilmu Kedokteran Gigi Pencegahan, Medika Fakultas Kedokteran UGM, Yogyakarta. 